\title{
Mammals, birds and reptiles of Dibru- Saikhowa Sanctuary, Assam, India
}

\author{
Anwaruddin Choudhury
}

\begin{abstract}
Dibru-Saikhowa Sanctuary protects $340 \mathrm{sq} \mathrm{km}$ of the floodplains of the
Brahmaputra and Lohit rivers in eastern Assam state, north-eastern India. It provides habitat for several threatened species, including Asian elephant and tiger. The sanctuary suffers from several problems, however, including illegal tree felling, the scarcity of safe, high ground for animals during the annual floods and insufficient staff and resources. The author makes recommendations for improving the conservation value of the sanctuary.
\end{abstract}

\section{Introduction}

Dibru-Saikhowa Wildlife Sanctuary (DSS) is located in the extreme east of Assam state, north-eastern India $\left(27^{\circ} 35^{\prime}-27^{\circ} 47^{\prime} \mathrm{N}, 9^{\circ} 10^{\prime}-\right.$ $\left.95^{\circ} 40^{\prime} \mathrm{E}\right)$. It covers part of two districts, Tinsukia and Dibrugarh, on the floodplains of the Brahmaputra and the Lohit rivers (Figure 1). The sanctuary was designated in 1986 and was to cover an area of $640 \mathrm{sq} \mathrm{km}$ but, when it was finally notified in 1995, the river beds of the Lohit and Brahmaputra rivers, and the Amarpur area were excluded, reducing its area to $340 \mathrm{sq} \mathrm{km}$. The DSS was once a large tract of tropical rain forest but during the earthquakes of 1950 a large part of the sanctuary sank by a few metres, resulting in regular flooding. The natural vegetation gradually changed and now the woodland is a tropical deciduous type (Choudhury, 1994b). Some of the largest Salix swamps remaining in northeastern India are found in the sanctuary. Characteristic species include Salix tetrasperma, Bischofia javanica, Dillenia indica, Terminalia myriocarpa and Lagerstroemia flos-reginae. The grassland and reedbeds are covered by tall grass species, such as Arundo donax, Phragmites karka, Erianthus ravennae, Imperata cylindrica Saccharum spontaneum and S. arundinaceum. The area has a tropical monsoon climate and the annual rainfall is $2300-3800 \mathrm{~mm}$.

The DSS provides habitat for Asian elephant*, tiger, Asiatic water buffalo (Choudhury, 1994a) as well as waterfowl, and is among the last strongholds of the white-winged wood duck, one of the rarest ducks in the world (Choudhury, 1996a). The adjacent forest pockets of Bherjan and Podumoni are very good areas for primates (Choudhury, 1995).

The primary objective of this study was to collect data on the presence and diversity of mammals, birds and reptiles (especially turtles and monitor lizards) in the DSS as well as adjacent areas including the Bherjan (1 sq $\mathrm{km})$ and Podumoni (1.7 sq km) Reserved Forests.

\section{Methods}

The surveys were conducted between July 1992 and May 1994, with short visits in 1995 and 1996. I surveyed the sanctuary using a small wooden boat (especially during the monsoon), on foot (especially during the dry winters), by motor-boat (on the Lohit River and once from Guijan to Burhibeel), using the transect method along existing forest trails, channels and rivers. All sightings and indirect evidence (pugmarks, tracks, faeces) were recorded. I also interviewed forest officials including guards, fishermen, hunters and graziers, especially about the conspicuous species that are easy to identify. In Bherjan and

\footnotetext{
* Scientific names of mammals, birds and reptiles mentioned in the text are given in Tables 1, 2 and 3.
} 


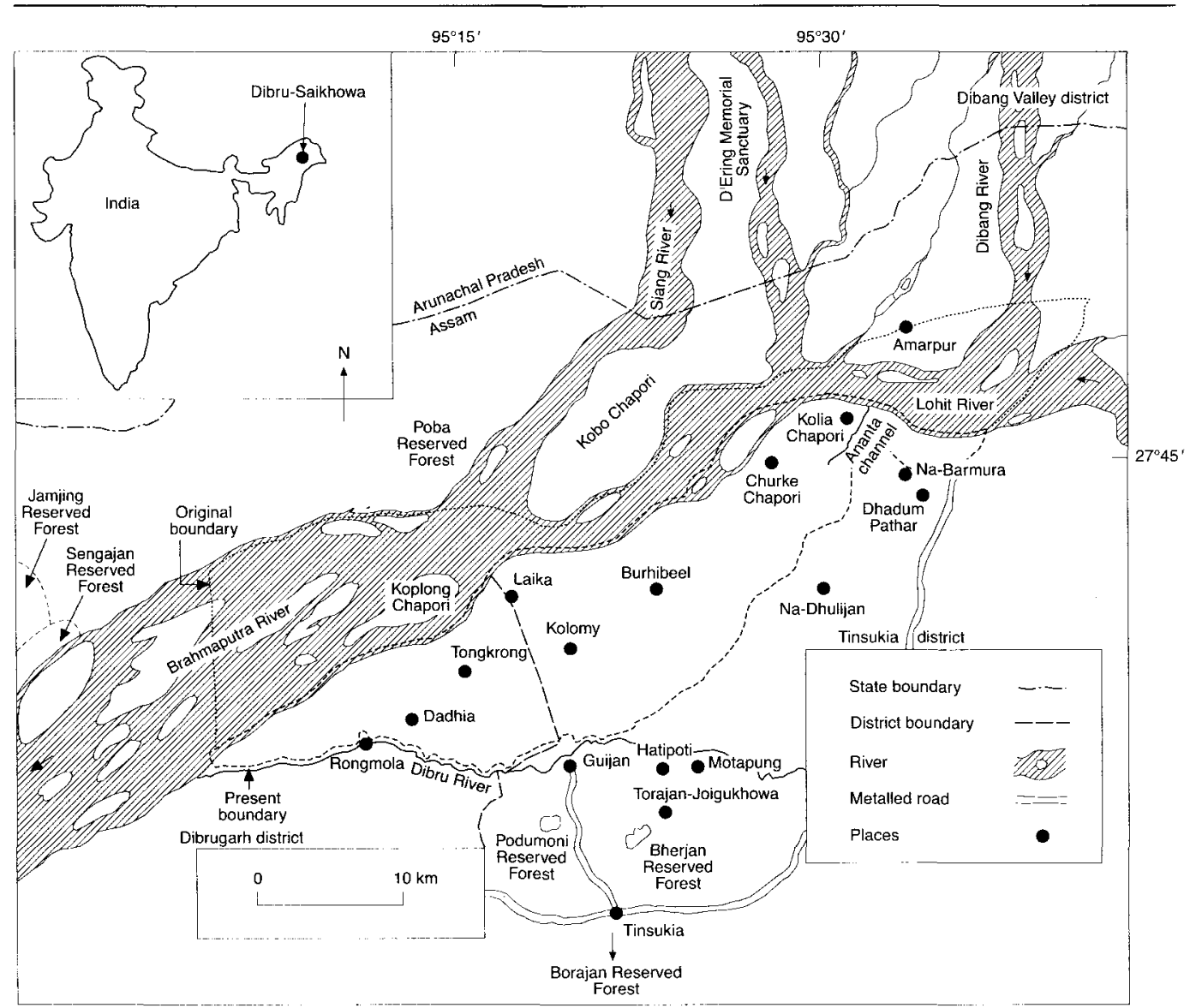

Figure 1. Dibru-Saikhowa Sanctuary, Assam, India.

Podumoni Reserved Forests, I carried out foot-transects along existing trails and roads. Daily records were made of observations or signs of all birds, mammals and reptiles.

In total, I spent $620 \mathrm{~h}$ spread over 78 days in the DSS and adjacent areas, and $311 \mathrm{~h}$ (71 days) and $28 \mathrm{~h}$ (13 days), respectively, in Bherjan and Podumoni Reserved Forests. The locations of the transects are shown in Figure 1. As a result of the long survey period, it was possible to record most of the larger species through direct sightings.

\section{Results}

I recorded the presence of 35 species of mammals (Table 1), while there were more species, such as bats and rodents, that could not be identified. To date 313 species of birds have been confirmed and some of the more notable of these are listed in Table 2. In the case of reptiles I could verify only 18 species (Table 3 ).

\section{Asian elephant}

I encountered Asian elephants throughout the area. They are among the most familiar mammals of the DSS and are unlikely to be missed by any visitor. Based on personal sightings, and interviews with forest officials and ex-mahouts, I estimated a fluctuating population of 150-400. A census carried out by the Forest Department in March 1993 using a direct count method found 131 elephants. Elephants regularly move out of the sanctuary, crossing the Brahmaputra and Lohit rivers to Kobo Chapori (chapori $=$ riverine island in the local 
Table 1. Mammal species identified in Dibru-Saikhowa Sanctuary (DSS) and adjacent areas

\begin{tabular}{|c|c|c|c|}
\hline English name & Scientific name & Method of identification & Status in DSS§ \\
\hline $\begin{array}{l}\text { Mole-shrew, Szechuan } \\
\text { burrowing shrew }{ }^{*}\end{array}$ & Anourosorex squamipes & Visual & Rare \\
\hline Indian flying fox & Pteropus giganteus & Visual & Common \\
\hline Slow loris & Nycticebus coucang & Past capture record & Rare \\
\hline Pig-tailed macaque & Macaca nemestrina & Visual & Raret \\
\hline Rhesus macaque & Macaca mulatta & Visual & Common \\
\hline Assamese macaque & Macaca assamensis & Visual & Raret \\
\hline Capped langur & Presbytis pileatus & Visual & Rare \\
\hline Hoolock gibbon & Hoolock gibbon & Visual & Rare \\
\hline Chinese pangolin & Manis pentadactyla & Local report & Rare \\
\hline Golden(-backed) jackal & Canis aureus & Visual/calls & Common \\
\hline Dhole, wild dog & Coun alpinus & Local report & Very rare \\
\hline Sloth bear & Ursus ursinus & Local report/tracks & Very rare \\
\hline Unidentified otter & Lutra/Lutrogale sp. & Tracks & Common \\
\hline Small Asian mongoose & Herpestes javanicus & Visual & Very common \\
\hline Unidentified small cats & Felis spp. & Tracks & Unknown \\
\hline Jungle cat & Felis chaus & Local report & Common \\
\hline Leopard cat & Felis bengalensis & Local report & Common \\
\hline Clouded leopard & Neofelis nebulosa & Visual (by N. Sharma) & Very rare \\
\hline Tiger & Panthera tigris & Tracks & Common \\
\hline Leopard & Panthera pardus & Visual, tracks, calls & Very rare \\
\hline Asian elephant & Elephas maximus & Visual/tracks/faeces/calls & Common \\
\hline Indian rhinoceros & Rhinoceros unicornis & Stray record in 1970 s & Stray \\
\hline Feral horse & Equus caballus & Visual & Rare \\
\hline Wild pig & Sus scrofa & Visual/tracks & Common \\
\hline Indian muntjac & Muntiacus muntjak & Tracks/preserved antlers & Common \\
\hline Hog deer & Axis porcinus & Visual/tracks & Common \\
\hline Sambar & Cervus unicolor & Tracks/preserved antlers & Rare \\
\hline Gaur $\neq$ & Bos gaurus & Tracks/local report & Very rare \\
\hline Wild water buffalo & Bubalus arnee/bubalis & Visual/tracks & Common \\
\hline Indian hare (rufous-tailed race) & $\begin{array}{l}\text { Lepus nigricollis } \\
\text { ruficaudatus }\end{array}$ & Visual/tracks & Common \\
\hline $\begin{array}{l}\text { Common giant flying squirrel } \\
\text { red flying squirrel }\end{array}$ & Petaurista petaurista & $\begin{array}{l}\text { Local report (visual } \\
\text { outside study area) }\end{array}$ & Common \\
\hline Particoloured flying squirrel & Hylopetes alboniger & $\begin{array}{l}\text { Local report (visual } \\
\text { outside study area) }\end{array}$ & Not known \\
\hline Pallas's squirrel & Callosciurus erythraeus & Visual & Common \\
\hline $\begin{array}{l}\text { Irrawaddy squirrel } \\
\text { Himalayan hoary-bellied } \\
\text { squirrel }\end{array}$ & Callosciurus pygerythrus & Visual & Common \\
\hline Malayan giant squirrel & Ratufa bicolor & Visual & Common \\
\hline $\begin{array}{l}\text { Crestless Himalayan porcupine } \\
\text { Chinese porcupine }\end{array}$ & Hystrix brachyura/hodgsoni & Local report/tracks & Common \\
\hline Gangetic dolphin & Platanista gangetica & Visual & Rare \\
\hline
\end{tabular}

* One dead specimen examined in Podumoni Reserved Forest.

t Rare in the DSS itself but common in Podumoni and Bherjan Reserved Forests.

₹ Seasonally only in the Amarpur area north of the Lohit river.

$\S$ Estimates of status are based on both primary sources (direct observations, signs and preserved specimens) and secondary sources (reports from forest staff, villagers and others) 
Table 2. Notable bird species, including those that are rare or endangered, identified in Dibru-Saikhowa Sanctuary and adjacent areas

\begin{tabular}{|c|c|c|c|c|}
\hline English name & Scientific name & $\begin{array}{l}\text { Method of } \\
\text { identification }\end{array}$ & $\begin{array}{l}\text { Status in } \\
\text { study areat }\end{array}$ & $\begin{array}{l}\text { Global } \\
\text { status }\end{array}$ \\
\hline Spot-billed pelican & Pelecanus philippensis & Visual & Rare & $\mathrm{T}$ \\
\hline Oriental darter & Anhinga melanogaster & Visual & Common & $\mathrm{N}$ \\
\hline White-bellied heron & Ardea insignis/imperialis & Visual (only once) & Rare & $\mathrm{T}$ \\
\hline $\begin{array}{l}\text { Malayan night heron, tiger } \\
\text { bittern }\end{array}$ & Gorsachius melanolophus & Visual & Rare & - \\
\hline Asian openbill stork & Anastomus oscitans & Visual & Common & $\mathrm{N}$ \\
\hline Black stork & Ciconia nigra & Visual & Common, winter & - \\
\hline Black-necked stork & Ephippiorhynchus asiaticus & Visual & Rare & - \\
\hline Greater adjutant stork & Leptoptilos dubius & Visual & Rare & $\mathrm{T}$ \\
\hline Lesser adjutant stork & Leptoptilos javanicus & Visual & Common & $\mathrm{T}$ \\
\hline Glossy ibis & Plegadis falcinellus & Visual & Rare & - \\
\hline Bar-headed goose & Anser indicus & Visual & Rare, winter & - \\
\hline $\begin{array}{l}\text { Fulvous tree duck, large } \\
\text { whistling teal }\end{array}$ & Dendrocygna bicolor & Visual & Rare & - \\
\hline Ferruginous pochard & Aythya nyroca & Visual & Rare, winter & $\mathrm{T}$ \\
\hline Baer's pochard & Aythya baeri & Visual & Rare, winter & $\mathrm{T}$ \\
\hline White-winged wood duck & Cairina scutulata & Visual/local report & Rare & $\mathrm{T}$ \\
\hline Black baza & Aviceda leuphotes & Visual & Rare & - \\
\hline Greater spotted eagle & Aquila clanga & Visual & Rare & $\mathrm{T}$ \\
\hline $\begin{array}{l}\text { Pallas's fish eagle, Pallas's } \\
\text { sea eagle }\end{array}$ & Haliaeetus leucoryphus & Visual & Rare & $\mathrm{T}$ \\
\hline $\begin{array}{l}\text { Lesser fish eagle, Himalayan } \\
\text { grey-headed fish eagle }\end{array}$ & Ichthyophaga humilis & Visual & Rare (only once) & $\mathrm{N}$ \\
\hline Grey-headed fish eagle & Ichthyophaga ichthyaetus & Visual & Common & $\mathrm{N}$ \\
\hline Cinereous vulture & Aegypius monachus & Visual & Rare, winter & $N$ \\
\hline Himalayan griffon vulture & Gyps himalayensis & Visual & Rare, winter & \\
\hline $\begin{array}{l}\text { Swamp partridge, swamp } \\
\text { francolin }\end{array}$ & Francolinus gularis & Calls & Rare & $\mathbf{T}$ \\
\hline Kaliej pheasant & Lophura leucomelanos & Visual/feathers & Common & - \\
\hline Red junglefowl & Gallus gallus & Calls & Common & - \\
\hline Common crane & Grus grus & Visual & Rare, W & - \\
\hline Sarus crane & Grus antigone & Visual & Very rare & $N$ \\
\hline Bengal florican* & Eupodotis bengalensis & Visual/local reports & Very rare & $\mathrm{T}$ \\
\hline Black-bellied tern & Sterna acuticauda & Visual & Rare & $\mathrm{T}$ \\
\hline $\begin{array}{l}\text { Pale-capped pigeon, purple } \\
\text { wood pigeon }\end{array}$ & Columba punicea & Visual & Rare & $\mathrm{T}$ \\
\hline Brown fish-owl & Ketupa zeylonensis & Visual & Rare & - \\
\hline Red-headed trogon & Harpactes erythrocephalus & Visual & Rare & - \\
\hline Blyth's kingfisher & Alcedo hercules & Visual & Rare & $\mathrm{T}$ \\
\hline Ruddy kingfisher & Halcyon coromanda & Visual & Rare & - \\
\hline Indian pied hornbill & $\begin{array}{l}\text { Anthracoceros albirostris/ } \\
\text { malabaricus }\end{array}$ & Visual/calls & Common & - \\
\hline Great pied hornbill & Buceros bicornis & Local report & Very rare & - \\
\hline Black-breasted parrotbill* & Paradoxornis flavirostris & Visual & Very rare & $\mathrm{T}$ \\
\hline Jerdon's bushchat & Saxicola jerdoni & Visual & Rare & $\mathrm{N}$ \\
\hline
\end{tabular}

* Sighted in the Amarpur area.

T, Threatened (Collar et al., 1994).

N, Near Threatened (Collar et al., 1994).

† Estimates of status in the study area are based on both primary sources (direct observations, signs and preserved specimens) and secondary sources (reports from forest staff, villagers and others). 
Table 3. Reptile species identified in Dibru-Saikhowa Sanctuary and adjacent areas

\begin{tabular}{|c|c|c|c|}
\hline English name & Scientific name & $\begin{array}{l}\text { Method of } \\
\text { identification }\end{array}$ & $\begin{array}{l}\text { Status in } \\
\text { study area* }\end{array}$ \\
\hline Gharial & Gavialis gangeticus & Local report & Very rare \\
\hline Malayan box turtle & Cuora amboinensis & Visual (live specimen) & Common \\
\hline Asian leaf turtle & Cyclemys dentata & Visual (preserved shell) & Uncommon \\
\hline Spotted pond turtle & Geoclemys hamiltonii & Visual (Preserved shell) & Uncommon \\
\hline Brown roofed turtle & Kachuga smithii & Visual (live specimen) & Uncommon \\
\hline Assam roofed turtle & Kachuga sylhetensis & Visual (live specimen) & Uncommon \\
\hline Tent turtle & Kachuga tentoria & Visual (live specimen) & Common \\
\hline Gangetic softshell & Aspideretes gangeticus & Visual (live specimen) & Common \\
\hline Peacock softshell & Aspideretes hurum & $\begin{array}{l}\text { Visual (live specimen from } \\
\text { outside study area) }\end{array}$ & Uncommon \\
\hline Narrow-headed softshell & Chitra indica & Visual (live specimen) & Uncommon \\
\hline $\begin{array}{l}\text { Common monitor, Bengal } \\
\text { monitor }\end{array}$ & Varanus bengalensis & Visual & Common \\
\hline Water monitor & Varanus salvator & Visual & Common \\
\hline Rock python & Python molurus & Local report & Uncommon \\
\hline Vine snake & Ahaetulla sp. & Visual & Common \\
\hline Rat snake & Ptyas / Coluber mucosus & Visual (skin) & Common \\
\hline Smooth water snake & Enhydris sp. & Visual & Uncommon \\
\hline Banded krait & Bungarus fasciatus & Local report & Common \\
\hline King cobra & Ophiophagus hannah & Local report & Uncommon \\
\hline
\end{tabular}

* Estimates of status in the study area are based on both primary sources (direct observations, signs and preserved specimens) and secondary sources (reports from forest staff, villagers and others).

Assamese language), Poba Reserved Forest and then to $D^{\prime}$ Ering Memorial Sanctuary in Arunachal Pradesh. Some also move to Jamjing and Sengajan Reserved Forests.

\section{Water buffalo}

Wild water buffalo were also common and recorded throughout the area. Most of the individuals seen were large, lone bulls, because the female and immature animals remain in the cover of woodland or dense grass/reeds during the day (unlike the behaviour of the species in Kaziranga National Park in Assam; Choudhury, 1994a). An estimate (based on a sample count in $c .30 \mathrm{sq} \mathrm{km}$ as well as field visits to other areas and interviews) suggested that at least 250 buffaloes survive in the DSS. There are also some feral buffaloes on the fringes of the area and at least two small herds of these animals were observed during the surveys. They were easily distinguished by their smaller body size, smaller horns and less aggressive behaviour. There are not likely to be any new feral buffaloes because domestic buffaloes are too valuable to their owners. The possibility of contamination of the wild stock as a result of hybridization with feral and domestic animals is unlikely. Wild bulls kill domestic males and for this reason domestic bulls are not usually kept in the villages and khutis (cattle and buffalo camps) on the edge of the sanctuary. A feral or stray domestic male has no chance of competing with wild bulls for access to wild females but some wild bulls join feral herds and regularly visit the khutis and villages on the edge of the sanctuary to mate with domestic female buffaloes. Therefore the gene flow is mostly one way.

\section{Cats}

I found pugmarks of tiger throughout almost the entire area. Tiger predation on cattle and buffalo in the khutis and fringe villages is not uncommon. Every year one or two tigers travel through tea plantations to visit Podumoni and Bherjan Reserved Forests. A 


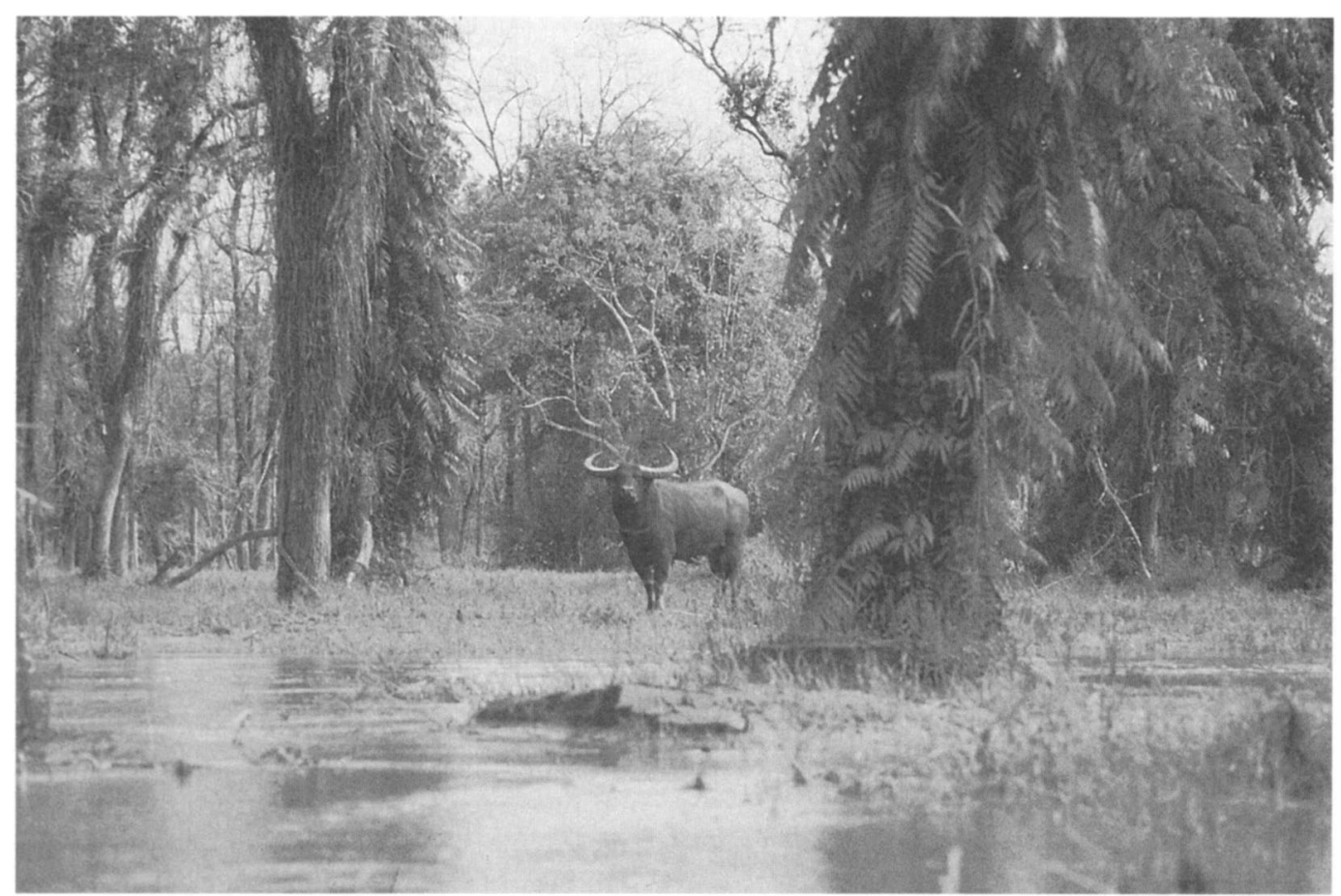

An immature wild water buffalo in Salix woodland (Anwaruddin Choudhury).

census carried out by the Forest Department using the 'pugmark count' method estimated that there were 27 tigers in 1993. My own assessment, based on field visits, interviews and records of cattle predation was 20-30 animals. Because of a fairly dense tiger population, the leopard is not found in the main sanctuary but mostly at the southern edge, including the tea plantations. However, it occurs in Podumoni Reserved Forest and Bherjan Reserved Forest. During the last 5 years at least 13 leopards captured from different tea estates and army cantonments south of the DSS were released inside the sanctuary. The clouded leopard has been recorded only once, in the Tongkrong area (N. Sharma, pers. comm.). The leopard cat and the jungle cat are the only smaller cats whose presence has been confirmed.

\section{Primates}

Hoolock gibbons were found in most of the sanctuary's woodland. The species disappeared from Podumoni Reserved Forest in the 1970s, while a lone female survives in Bherjan Reserved Forest. There are some small isolated populations in some of the larger village woodlands near the DSS: Motapung, TorajanJoigukhowa and Na-Dhulijan. Although 31 groups were verified from sightings and calls (28 in the DSS and three outside), local reports and the extent of suitable habitat suggest the presence of at least another 20 groups in the DSS.

The rhesus macaque is abundant throughout the DSS and adjacent tea estates, but not in Bherjan and Podumoni. In these two pockets of forest, Assamese and pig-tailed macaques are abundant but they are rare inside the DSS.

The capped langur was found in the DSS and Podumoni but not in Bherjan. A small population survives in the village woodlands of Hatipoti-Motapung areas, north of Bherjan. The slow loris was seldom seen but past captures confirm its presence in the DSS and Bherjan. This species is, perhaps, extinct in Podumoni. 


\section{Other mammals}

Gaur tracks were found in the Amarpur area outside the DSS. Gaur visit this area in winter, descending from the Dibang Valley district of Arunachal Pradesh. Other mammals seen during the survey included flying fox, wild pig, Malayan giant squirrel, Pallas's squirrel, Irrawaddy squirrel, Szechuan burrowingshrew (in Podumoni) and Gangetic dolphin. Tracks of sambar, hog deer and muntjac were found regularly. Preserved antlers were seen in many of the fringe villages. The sloth bear and dhole are vanishing as a result of the regular flooding but individuals of both species are still found.

The DSS has an interesting population of feral horses (true feral: i.e. born free and living free). Numbering fewer than 100, these animals are found in three herds in Churke Chapori and Kolia Chapori.

\section{Birds}

To date, 313 species of birds have been confirmed from the sanctuary. Many nocturnal species and those that live in dense undergrowth were poorly represented in the surveys, suggesting that a higher number of species occurs than has been recorded. Some notable species are listed in Table 2. The DSS is an important wintering ground for waterfowl, and the white-winged wood duck is a rare resident. The Bengal florican is found in the grassland areas.

The sarus crane was recorded in Dhadum Pathar (pathar = field in the local Assamese language), outside the DSS in March 1994, the only record of the species in north-east India for several decades. The birds were of the nominate race Grus antigone antigone, whose known eastern limit was western Assam $\left(92^{\circ} \mathrm{E}\right)$. The 1994 record extended the known range by about $500 \mathrm{~km}\left(95^{\circ} 35^{\prime} \mathrm{E}\right)$.

The DSS and adjacent areas, including parts of Arunachal Pradesh, are important staging areas for migratory waterfowl, including the common crane. A new migration route of the common crane was discovered near the DSS (Choudhury, 1994c,d).
The grey or Himalayan treepie Dendrocitta formosae and white-throated bulbul Criniger flaveolus, whose known residential range was above $600 \mathrm{~m}$ (Ali and Ripley, 1983), were found to be resident at $100 \mathrm{~m}$ (these two species are also found elsewhere in Assam at similar or even lower elevations; A.U. Choudhury, unpublished data). The survey also extended the eastern range of the nominate race of the spot-billed duck Anas poecilorhyncha, Eurasian griffon vulture Gyps fulvus and bank myna Acridotheres ginginianus. Other notable sightings included white-bellied heron and black-breasted parrotbill.

\section{Reptiles}

Among reptiles, turtles were covered comprehensively, based on actual sightings in the wild, identification from captured specimens and preserved shells collected from fringe villages. Nine species were recorded, including sightings of the narrow-headed softshell and Gangetic softshell, which had not been previously recorded in Assam (Das, 1991). The eastern ranges of the Malayan box turtle, spotted pond turtle, brown roof turtle and Assam roof turtle were extended considerably by this survey. The record of Asian leaf turtle in the DSS is the first for the species from alluvial floodplains.

Both common, or Bengal, monitor and water monitor were found to be common. Only a few species of snakes could be verified during the survey, although many more are present. The gharial has become extremely rare, with only a handful of reports from the Brahmaputra, Lohit and Dibru rivers. Table 3 lists the reptiles recorded.

\section{Conservation problems}

The DSS was commercially logged before notification as a sanctuary, which resulted in large areas being cleared. At present, illegal felling with the help and connivance of the forest villagers of Laika and Dadhia and some fringe villagers, is causing concern to the authorities. The forest villagers have also encroached 


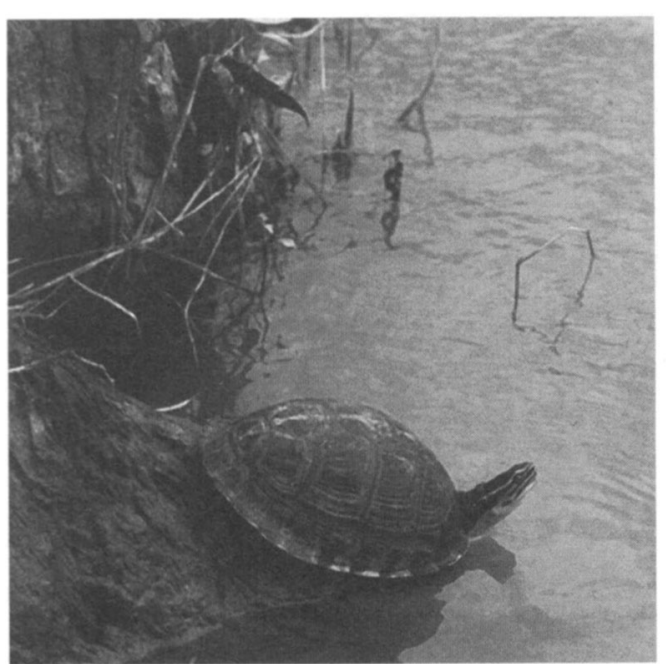

A Malayan box turtle (Anwaruddin Choudhury).

upon some forest land adjacent to their areas within the sanctuary but there are no encroachments from outside. About 9000 cattle and domestic buffaloes graze in the grasslands, especially in the fringe areas.

The waterbodies of the DSS are frequently used by small-time fishermen. Of most concern to the authorities is the use of poisons, such as Thiodan (a dangerous non-biodegradable pesticide used on the tea estates) by some fishermen to kill fish, especially in winter. Poaching is not a serious problem, except during floods, when deer and pigs moving to higher ground are killed in the tea estates and villages. The sale of turtles in the markets adjacent to the DSS has been stopped successfully by the authorities.

Flooding is a serious problem for the DSS, but Bherjan and Podumoni are above the reach of the floods. Many of the terrestrial mammals and birds drown or starve during severe floods. Erosion by the Brahmaputra and Lohit rivers and innumerable channels such as Kolomy, Ananta and Dadhia, also threaten rich grassland and woodland. Another major problem hindering conservation is insufficient infrastructure; only some 70 or so staff are distributed among the Guijan and Na-Barmura ranges and seven to nine camps.

\section{Recommendations}

- Part of the area excluded during final notification of the sanctuary should be added. This should include the southern part of Amarpur, Koplong Chapori and some riverine stretches.

- A well defined core area should be designated as proposed by Choudhury (c. $190 \mathrm{sq}$ $\mathrm{km} ; 1994 \mathrm{~b}$ ), where human disturbance should be kept to the barest minimum.

- Efforts should be made to translocate Laika and Dadhia forest villages out of the sanctuary.

- More forest camps are needed, including mobile ones on boats, and more patrolling staff should be recruited.

- A radio network should be set up to link the forest camps and patrols with the range headquarters.

- Raised roads and platforms should be built to provide wildlife refuges during floods.

- Domestic stock should be inoculated regularly to prevent the possible spread of anthrax, rinderpest, etc. to wild ungulates. Non-governmental organizations, which did excellent work inoculating domestic stock on the fringes of Kaziranga and other reserves during 1995-96 (Choudhury, 1996b), could repeat these activities around the DSS, especially given the presence of a viable population of wild water buffalo.

- The DSS has already been proposed as a biosphere reserve as well as a tiger reserve (under Project Tiger). All the adjacent wildlife habitats, such as Kobo Chapori and Poba Reserved Forest, should also be included as part of this reserve. Bherjan, Podumoni and Borajan Reserved Forests should also be accorded sanctuary status.

\section{Acknowledgements}

For their assistance during the field surveys, I would like to thank R. Bhattacharjee (DFO), T. Das (ACF), Narayan Sharma (RO) and other forest staff, Paniram Das, Nur Husain, Ranjit Doley, Dilip, Babul, M. Pegu (APO), Munin Hazarika (JE), Bolo Paul and Mridu Phukan. I also thank the Oriental Bird Club for a small grant (assisted by Naturetrek), towards the bird surveys, and the Assam Science 


\section{A. CHOUDHURY}

Technology and Environment Council for a grant towards the primate surveys.

\section{References}

Ali, S. and Ripley, S.D. 1983. Handbook of the Birds of India and Pakistan. Oxford University Press, Delhi.

Choudhury, A.U. 1994a. The decline of the wild water buffalo in north-eastern India. Oryx, 28 (1), 70-73.

Choudhury, A.U. 1994b. A Report on Bird Survey in Dibru-Saikhowa Wildlife Sanctuary, Assam, India. Report to the Oriental Bird Club, UK.

Choudhury, A.U. 1994c. A new crane-migration route discovered. Asian Wetland News, 7 (1), 18.

Choudhury, A.U. 1994d. Discovery of a new cranemigration route and the first mid-winter waterfowl census in Arunachal Pradesh. Newsletter for Birdwatchers, 34 (6), 135-137.

Choudhury, A.U. 1995. Wildlife Suroey in Bherjan, Borajan and Podumoni RFs of Tinsukia District,
Assam, with a Proposal for a Wildlife Sanctuary. The Rhino Foundation for Nature in NE India, Guwahati.

Choudhury, A.U. 1996a. Survey of the White-winged Wood Duck and the Bengal Florican in Tinsukia District and Adjacent Areas. The Rhino Foundation for Nature in NE India, Guwahati.

Choudhury, A.U. 1996b. The Rhino Foundation in the field. Newsletter of the Rhino Foundation for Nature in NE India, 1 (1), 1-7.

Collar, N.J., Crosby, M.J. and Stattersfield, A.J. 1994. Birds to Watch 2: The World List of Threatened Birds. BirdLife International, Cambridge.

Anwaruddin Choudhury, The Rhino Foundation for Nature in NE India, c/o The Assam Co. Ltd, G. Bordoloi Path, Bamunimaidam, Guwahati 781 021, Assam, India.

Received 7 March 1997

Accepted 1 December 1997 